\title{
Female consumers buying behaviour for fashion apparels: an exploratory study
}

\author{
Meenakshi Mishra and Sudha Babel
}

Received: 22.02.2020; Revised: 25.03.2020; Accepted: 10.05 .2020

See end of the paper for authors' affiliations

Meenakshi Mishra

Department of Textiles and Apparel Designing, College of

Community and Applied Sciences, Maharana Pratap University of Agriculture and Technology, Udaipur (Rajasthan) India

Email : meenakshimishra57

@gmail.com
ABSTRACT : Apparel is billion-dollar industry employing millions of the people around the world. Over the last one decade, apparel industry has gone through the drastic change in the world market. Indian garment industry is very diverse in size, manufacturing facility, type of apparel produced, quantity and quality of output, cost and requirement for fabric etc. It comprises suppliers of ready-made garments for both, domestic or exports markets. This study is targeted on females buying behaviour for the purchase of their apparel. Women in age range of 16-45 year were selected for the study. Structured questionnaire and personal interview method was used for data collection data were coded and analyzed. Results revealed that availability of fund is major factor for purchase for middle age women, they occasionally purchase clothes, and usually purchase formal wear i.e. tighties and kurties. College girls' apparel buying behaviour revealed that they usually purchase clothes monthly and availability of funds is least important factor for them. Apparel buying behaviour of girls is affected by friends while of middle age women decision to buy is affected by husband.

KEY WORDS: Apparel Industry, Buying behaviour, Female preference in design, Fashion apparel, Apparel preference

- HOW TO CITE THIS PAPER : Mishra, Meenakshi and Babel, Sudha (2020). Female consumers buying behaviour for fashion apparels: an exploratory study. Asian J. Home Sci., 15 (1) : 125-129, DOI: 10.15740/ HAS/AJHS/15.1/125-129. Copyright@ 2020: Hind Agri-Horticultural Society. 